\title{
Erratum to: Novel C-terminal Hsp90 Inhibitor for Head and Neck Squamous Cell Cancer (HNSCC) with in vivo Efficacy and Improved Toxicity Profiles Compared with Standard Agents
}

\author{
Stephanie M. Cohen, MD ${ }^{1}$, Ridhwi Mukerji, MD ${ }^{1}$, Abbas K. Samadi, $\mathrm{PhD}^{1}$, Xuan $\mathrm{Zhang} \mathrm{PhD}^{\mathbf{1}}$, \\ Huiping Zhao, PhD $^{2}$, Brian S. J. Blagg, PhD $^{2}$, and Mark S. Cohen, MD, FACS ${ }^{1}$ \\ ${ }^{1}$ Department of Surgery, University of Kansas Medical Center, Kansas City, KS; ${ }^{2}$ Department of Medicinal Chemistry, \\ University of Kansas, Lawrence, KS
}

\section{ERRATUM TO: ANN SURG ONCOL \\ DOI 10.1245/S10434-011-1971-1}

In the original article, Xuan Zhang, $\mathrm{PhD}$, was inadvertently left off the author byline. The byline is republished here correctly.

Stephanie M. Cohen and Ridhwi Mukerji are co-first authors.

The online version of the original article can be found under doi:10.1245/s10434-011-1971-1.

(C) Society of Surgical Oncology 2012

Published Online: 7 March 2012

S. M. Cohen, MD

e-mail: scohen@kumc.edu 